\title{
»Ei døden agter alder stort«
}

Af Tage Holm.

Hvem kan blade $i$ en gammel kirkebogs afsnit De Dødes Register « uden med andagt i sindet? Her møder man jo de mørke tråde i det mønster, som tegner den gamle slægts liv.

Når man sysler med fortidens mennesker, deres gerninger, deres tanker, må man aldrig glemme, at de havde døden meget nær inde på livet:

Kom menneske, betragte mig,

Du er, jeg var $i$ live,

$P d$ jorden har jeg lignet dig,

Hoad jeg er, skal du blive,

Jeg gik foran,

Mig folger du,

Tank derfor ei $i$ sind og hu,

At du kan daden vige.

Bered dig, gak fra verden ud,

Betænk dit lives ende,

Noir man foragter dodens bud,

Har man den tidt $i$ hande,

I dag er det tilfaldet mig,

$I$ morgen kan det gielde dig,

Ja, muligt denne aften.

Siig ei: jeg er af ungdoms flok, Jeg kan her lange blive,

Akl nei, du er snart gammel nok,

Din and fra dig at give,

Det meget snart med dig er gjort;

Ei doden agter alder stort,

Hvi vil du andet tanke?

(Pontoppidan nr. 484) ${ }^{1}$

»Ei døden agter alder stort ... kan stå som overskrift over efterfølgende undersøgelse over børnedødelighedens størrelse og 
årsager $\mathrm{i}$ et lille sogn her $\mathrm{i}$ midtlandet $\mathrm{i}$ et århundrede fra 17641864.

Denne lille undersagelse gør intet krav på fuldstændighed. Den kan vel heller ikke kaldes typisk for landsdelen — i så fald måtte langt større omrâder tages med. Den gør kun krav på at give et billede af livet her i Jegerup sogn ${ }^{2}$ - under dødens trussel - i disse år.

$\mathrm{Nu}$ først nogle tal. I efterfolgende skema er på grundlag af dødsregisteret $\mathrm{i}$ Jegerup sogns ministerialbøger anført dødsfaldenes fordeling efter alder i de omtalte ti 10-år.

Antallet af døde i Jegerup sogn

$1764-1863$

\begin{tabular}{|c|c|c|c|c|c|c|c|c|c|c|c|c|}
\hline & 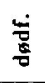 & $\frac{\dot{n}}{\delta}$ & $\Xi$ & $\underset{\text { స̃ }}{\stackrel{d}{\Xi}}$ & 品 & $\stackrel{9}{\dot{9}}$ & $\stackrel{\overline{\hat{s}}}{\underline{s}}$ & 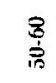 & $\underset{⿱ 乛}{\tilde{z}}$ & 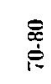 & $\frac{1}{8}$ & $\frac{ \pm}{\underline{\pi}}$ \\
\hline 1764 & 2 & 1 & 2 & 0 & 1 & 0 & 0 & 0 & 0 & 0 & 1 & 7 \\
\hline 1765 & 0 & 3 & 3 & 0 & 0 & 0 & 0 & 2 & 0 & 0 & 2 & 10 \\
\hline 1766 & 0 & () & 2 & 0 & 1 & 1 & 1 & 0 & 0 & 0 & 0 & 5 \\
\hline 1767 & 0 & 2 & 2 & $\mathbf{t}$ & 1 & 0 & 0 & 2 & 0 & 3 & 2 & 13 \\
\hline 1768 & 1 & 2 & 1 & 0 & 0 & 0 & 1 & 0 & 1 & 1 & 2 & 9 \\
\hline 1769 & () & 1 & 1 & 0 & 4 & 0 & 0 & 2 & 0 & 0 & 1 & 9 \\
\hline 1770 & 0 & 0 & 2 & 2 & 1 & 0 & 1 & 2 & 0 & 1 & 1 & 10 \\
\hline 1771 & 1 & 2 & 4 & 1 & 0 & 0 & 0 & 1 & 1 & 1 & 0 & 10 \\
\hline 1772 & () & 3 & 1 & 0 & 0 & 0 & 1 & 2 & 1 & 4 & 0 & 12 \\
\hline \multirow[t]{2}{*}{1773} & 0 & 1 & 1 & 0 & 0 & 1 & 0 & 0 & 2 & 1 & 1 & 7 \\
\hline & 4 & 15 & 19 & 4 & 8 & 2 & 4 & 11 & 5 & 11 & 10 & 92 \\
\hline
\end{tabular}

\begin{tabular}{rrrrllllllllr}
1774 & 0 & 3 & 1 & 0 & 1 & 0 & 0 & 4 & 2 & 0 & 0 & 11 \\
1775 & 0 & 0 & 1 & 0 & 0 & 0 & 2 & 0 & 0 & 1 & 1 & 5 \\
1776 & 1 & 2 & 0 & 0 & 0 & 0 & 1 & 0 & 1 & 1 & 0 & 6 \\
1777 & 0 & 2 & 2 & 0 & 1 & 1 & 0 & 4 & 1 & 0 & 2 & 13 \\
1778 & 0 & 3 & 9 & 2 & 0 & 0 & 0 & 1 & 1 & 1 & 0 & 17 \\
1779 & 2 & 0 & 1 & 0 & 0 & 0 & 0 & 0 & 1 & 0 & 0 & 4 \\
1780 & 1 & 3 & 1 & 1 & 0 & 1 & 0 & 0 & 0 & 1 & 1 & 9 \\
1781 & 0 & 1 & 0 & 0 & 0 & 0 & 0 & 1 & 0 & 0 & 1 & 3 \\
1782 & 3 & 0 & 3 & 0 & 1 & 1 & 0 & 0 & 1 & 1 & 1 & 11 \\
1783 & 0 & 1 & 0 & 2 & 0 & 2 & 1 & 0 & 1 & 2 & 0 & 9 \\
\hline & 7 & 15 & 18 & 5 & 3 & 5 & 4 & 10 & 8 & 7 & 6 & 88 \\
\hline
\end{tabular}




\section{妾}

$\begin{array}{lllllllllllll}1824 & 0 & 1 & 4 & 1 & 0 & 0 & 0 & 2 & 0 & 1 & 1 & 10\end{array}$

$\begin{array}{lllllllllllll}1825 & 0 & 1 & 1 & 0 & 0 & 0 & 2 & 0 & 0 & 0 & 0 & 4\end{array}$

$\begin{array}{lllllllllllll}1826 & 0 & 1 & 2 & 1 & 2 & 1 & 2 & 0 & 3 & 0 & 1 & 13\end{array}$

$\begin{array}{lllllllllllll}1827 & 0 & 7 & 5 & 3 & 0 & 1 & 0 & 0 & 2 & 4 & 0 & 22\end{array}$

$\begin{array}{lllllllllllll}1828 & 0 & 3 & 3 & 1 & 1 & 0 & 1 & 0 & 0 & 1 & 0 & 10\end{array}$

$\begin{array}{rlllllllllllr}1829 & 0 & 1 & 1 & 0 & 1 & 0 & 0 & 0 & 1 & 6 & 3 & 13\end{array}$

$\begin{array}{lllllllllllll}1830 & 0 & 0 & 1 & 2 & 0 & 1 & 0 & 1 & 1 & 2 & 1 & 8\end{array}$

$\begin{array}{lllllllllllll}1831 & 2 & 1 & 0 & 0 & 0 & 0 & 1 & 1 & 2 & 1 & 1 & 9\end{array}$

$\begin{array}{lllllllllllll}1832 & 2 & 1 & 4 & 0 & 1 & 2 & 1 & 0 & 1 & 5 & 0 & 17\end{array}$

$\begin{array}{rrrrrrrrrrrrr}1833 & 1 & 1 & 3 & 0 & 0 & 1 & 0 & 2 & 0 & 3 & 0 & 11 \\ & 5 & 17 & 24 & 8 & 5 & 6 & 7 & 6 & 10 & 22 & 7 & 118\end{array}$

\begin{tabular}{lllllllllllll}
\hline 1834 & 2 & 3 & 6 & 1 & 0 & 0 & 0 & 1 & 0 & 1 & 0 & 14
\end{tabular}

$\begin{array}{rllllllllllll}1835 & 1 & 1 & 0 & 0 & 0 & 1 & 0 & 1 & 1 & 1 & 1 & 7\end{array}$

$\begin{array}{lllllllllllll}1836 & 1 & 2 & 0 & 0 & 0 & 1 & 1 & 4 & 0 & 2 & 2 & 13\end{array}$

$\begin{array}{lllllllllllll}1837 & 2 & 1 & 6 & 0 & 0 & 1 & 1 & 3 & 1 & 1 & 0 & 17\end{array}$

$\begin{array}{lllllllllllll}1838 & 0 & 3 & 3 & 1 & 1 & 0 & 0 & 1 & 2 & 1 & 1 & 13\end{array}$

$\begin{array}{lllllllllllll}1839 & 5 & 2 & 6 & 0 & 1 & 1 & 1 & 0 & 0 & 0 & 1 & 17\end{array}$

$\begin{array}{lllllllllllll}1840 & 0 & 4 & 3 & 0 & 1 & 0 & 1 & 1 & 0 & 2 & 2 & 14\end{array}$

$\begin{array}{lllllllllllll}1841 & 0 & 2 & 1 & 1 & 0 & 1 & 0 & 1 & 1 & 4 & 2 & 13\end{array}$

$\begin{array}{lllllllllllll}1842 & 1 & 1 & 2 & 1 & 0 & 0 & 2 & 1 & 3 & 0 & 1 & 12\end{array}$

\begin{tabular}{rrrrrrrrrrrrr}
1843 & 1 & 3 & 3 & 1 & 1 & 2 & 2 & 0 & 2 & 2 & 1 & 18 \\
\hline
\end{tabular}

\begin{tabular}{lllllllllllll}
\hline 1844 & 0 & 2 & 3 & 1 & 0 & 0 & 1 & 1 & 3 & 2 & 0 & 13
\end{tabular}

$\begin{array}{lllllllllllll}1845 & 0 & 2 & 2 & 1 & 2 & 2 & 0 & 1 & 2 & 2 & 0 & 14\end{array}$

$\begin{array}{lllllllllllll}1846 & 1 & 2 & 2 & 1 & 2 & 2 & 1 & 1 & 0 & 0 & 1 & 13\end{array}$

$\begin{array}{lllllllllllll}1847 & 0 & 2 & 0 & 0 & 0 & 0 & 2 & 1 & 1 & 0 & 1 & 7\end{array}$

$\begin{array}{lllllllllllll}1848 & 1 & 0 & 3 & 0 & 0 & 0 & 0 & 0 & 0 & 1 & 0 & 5\end{array}$

$\begin{array}{lllllllllllll}1849 & 0 & 4 & 3 & 1 & 2 & 0 & 2 & 0 & 0 & 0 & 1 & 13\end{array}$

$\begin{array}{lllllllllllll}1850 & 1 & 4 & 1 & 3 & 0 & 3 & 0 & 1 & 1 & 2 & 0 & 16\end{array}$

$\begin{array}{lllllllllllll}1851 & 1 & 2 & 2 & 1 & 1 & 1 & 2 & 2 & 2 & 0 & 0 & 14\end{array}$

$\begin{array}{lllllllllllll}1852 & 1 & 6 & 7 & 1 & 0 & 0 & 1 & 0 & 0 & 1 & 0 & 17\end{array}$

\begin{tabular}{rrrrrrrrrrrrr}
1853 & 1 & 3 & 1 & 0 & 1 & 0 & 0 & 1 & 0 & 0 & 1 & 8 \\
\hline
\end{tabular}

\begin{tabular}{rrrrrrrrrrrrr} 
& 6 & 27 & 24 & 8 & 8 & 8 & 9 & 8 & 9 & 8 & 4 & 120 \\
\hline 1854 & 0 & 3 & 4 & 1 & 0 & 0 & 0 & 1 & 0 & 0 & 2 & 11
\end{tabular}

$\begin{array}{lllllllllllll}1855 & 1 & 3 & 1 & 2 & 0 & 0 & 4 & 2 & 2 & 1 & 0 & 16\end{array}$

$\begin{array}{lllllllllllll}1856 & 3 & 1 & 1 & 1 & 1 & 2 & 1 & 2 & 2 & 1 & 2 & 17\end{array}$

$\begin{array}{lllllllllllll}1857 & 0 & 0 & 7 & 0 & 1 & 3 & 1 & 4 & 1 & 3 & 1 & 21\end{array}$

$\begin{array}{lllllllllllll}1858 & 1 & 2 & 5 & 1 & 0 & 1 & 3 & 1 & 2 & 3 & 1 & 20\end{array}$

$\begin{array}{lllllllllllll}1859 & 0 & 2 & 5 & 2 & 1 & 0 & 0 & 1 & 0 & 2 & 0 & 13\end{array}$

$\begin{array}{lllllllllllll}1860 & 1 & 0 & 3 & 2 & 0 & 1 & 0 & 2 & 2 & 0 & 0 & 11\end{array}$

$\begin{array}{rlllllllllllr}1861 & 0 & 2 & 0 & 2 & 0 & 1 & 1 & 0 & 0 & 0 & 0 & 6\end{array}$

$\begin{array}{lllllllllllll}1862 & 0 & 0 & 1 & 1 & 2 & 1 & 0 & 4 & 0 & 4 & 1 & 14\end{array}$

$\begin{array}{rrrrrrrrrrrrr}1863 & 1 & 0 & 0 & 0 & 0 & 1 & 3 & 0 & 3 & 2 & 1 & 11 \\ & 7 & 13 & 27 & 12 & 5 & 10 & 13 & 17 & 12 & 16 & 8 & 140\end{array}$


Den farligste alder er det første leveår, dernæst de følgende barneår 1-10, så aftager risikoen for atter at stige hen mod støvets år. Det er jo sådan set forbavsende mange, som har nået oldingealderen, før døden indtræffer.

Af praktiske grunde skiller vi nu de første 3 aldersgrupper ud, henregner altså hele gruppen fra 1 til 20 år til børnene og kan så i tal og procenter angive børnedødeligheden i forholdet til tallet af levendefødte. Vi kan altså på denne måde se hvor mange børn, der bliver tilbage, når døden har gjort sin høst.

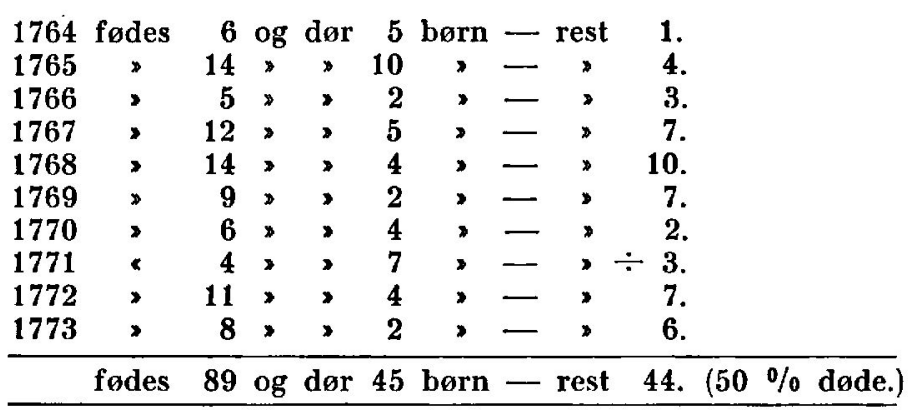

\begin{tabular}{|c|c|c|c|c|c|c|c|c|}
\hline $1 x$ & les & 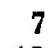 & og & dør & 4 & ørn & 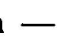 & rest \\
\hline 775 & , & 13 & , & , & 1 & , & - & 12 \\
\hline 7 & ॥ & 8 & . & , & & > & - & $D$ \\
\hline 7 & * & 17 & ॥ & , & & \$ & - & 13 \\
\hline & \# & 9 & , & 》 & 14 & & - & -5 \\
\hline & » & 17 & , & 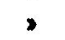 & & 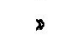 & - & 14 \\
\hline & ॥ & 8 & . & & & 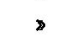 & $\ldots$ & 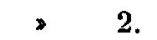 \\
\hline & $\gg$ & 6 & , & & & > & - & » \\
\hline & . & 10 & , & & & , & - & , \\
\hline 78 & 》 & 11 & " & 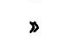 & & " & & \$ \\
\hline
\end{tabular}

fødes 106 og dor 45 børn - rest 61 . $(42,4 \%$ døde.)

\begin{tabular}{|c|c|c|c|c|c|c|c|c|}
\hline 1784 & fødes & 10 & og & dør & 8 & børn & - & rest \\
\hline 1785 & * & 14 & , & $\gg$ & 0 & s & 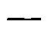 & 14. \\
\hline 1786 & $\geqslant$ & 9 & , & * & 12 & * & - & $\not \div 3$. \\
\hline 1787 & * & 9 & , & . & 5 & , & - & 4 \\
\hline 1788 & 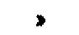 & 19 & , & , & 8 & > & - & 11 \\
\hline 1789 & * & 9 & , & > & 7 & > & 一 & 2. \\
\hline 1790 & , & 15 & \ & > & 4 & 》 & - & 11. \\
\hline 1791 & \ & 15 & > & , & 7 & , & - & 8. \\
\hline 1792 & $\star$ & 17 & , & , & 4 & > & 一 & 13. \\
\hline 1793 & 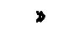 & 18 & , & 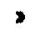 & 6 & 》 & - & 12 \\
\hline
\end{tabular}

fødes 135 og dør 61 børn - rest $74 .(45 \%$ døde.) 
1794 fødes 15 og dor 16 børn - rest $\div 1$.

$1795>17>>3$, $>14$.

$1796 \geqslant 15 \geqslant, 3 \geqslant->12$.

1797 " 18 " 3 " $>15$.

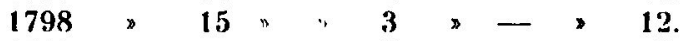

$1799,12 \gg, 5$ - $\$ 7$.

$1800 " 13 \gg, 12$ " $"$, 1 .

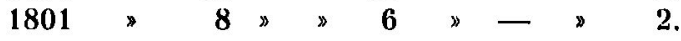

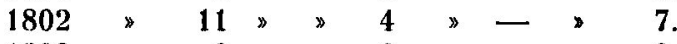

$1803,9, \quad 6, \ldots, 3$.

fødes 133 og dør $6 1 \longdiv { \text { born } - \text { rest } 7 2 . \quad ( 4 5 \% \text { døde.) } }$

1804 fødes 16 og dor 2 børn - rest 14 .

$1805,12 \geqslant, 6,-, 6$.

$1806,16,24,-12$.

1807,8 8 $\$ 1$ - $\$ 7$.

$1808 \gg 11 \gg, 2 \gg-\$ 9$.

$1809,10,>3,-, 7$.

$1810,11 \gg, 3>-, 8$.

$1811,16 \gg, 5$, $\$ 11$.

$1812,10,75 \times-, 5$.

$1813,14 *>4>->10$.

fødes 124 og dor 35 børn - rest 89. (29\% døde.)

1814 fødes 9 og dor 3 børn - rest 6.

$1815,13, \gg 2,->11$.

$1816 \gg 14 \gg, 6 \gg-\$ 8$.

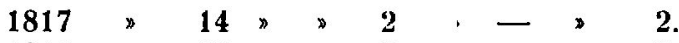

$1818,10 \times>2,->8$.

$1819 \gg 12 \gg, 3 \gg-\$ 9$.

1820,17 > 4 ,, 13.

$1821,15,>8,->7$.

$1822,19 *>4 \times->15$.

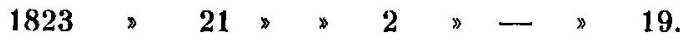

fødes 144 og dør 36 børn - rest 108 . (25,6\% døde.)

1824 fødes 14 og dør 6 børn — rest 8.

1825,15 , 2 , — 13 .

$1826>20>\nabla 4>->16$.

$1827 \diamond 19 * \star 15 \gg->>4$.

$1828 \gg 15 \gg \gg 7$ - $\gg 8$.

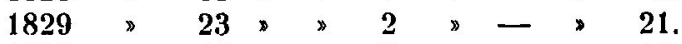

1830 " 15 " $" 3$ " 3 " 12.

1831 . 16 " 1 - 15.

$1832,1455,9$

1833,27 " 43 --

fodes 178 og dor 49 born - rest 129 . (27,5\% døde.) 


\begin{tabular}{|c|c|c|c|c|c|c|c|c|c|}
\hline 334 & odes & 15 & og & $\mathrm{d} ø \mathbf{r}$ & 10 & born & - & rest & 5. \\
\hline 835 & * & 22 & $\star$ & $\Rightarrow$ & 1 & > & - & * & 21 . \\
\hline 836 & 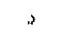 & 22 & $»$ & : & 2 & $\Rightarrow$ & - & " & 0. \\
\hline 337 & & 19 & " & . & 7 & " & $\ldots$ & 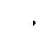 & 12 \\
\hline 338 & 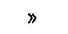 & 22 & 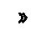 & , & 7 & , & - & $\Rightarrow$ & \\
\hline 33 & > & 19 & $"$ & $n$ & 8 & " & - & $"$ & \\
\hline 840 & \# & 21 & " & 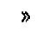 & 7 & , & - & $x$ & \\
\hline 841 & . & 14 & , & $\varnothing$ & 4 & . & - & , & \\
\hline 842 & $\gg$ & 15 & » & " & 4 & $\pi$ & - & 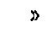 & \\
\hline 843 & > & 22 & * & 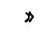 & 7 & $\nu$ & - & $\gg$ & \\
\hline
\end{tabular}

fodes 191 og dor 57 burn - rest $134 .(29 \%$ dode.)

\begin{tabular}{|c|c|c|c|c|c|c|c|c|}
\hline 844 & fodes & 13 & og dør & 6 & børn & - & rest & $\cdots$ \\
\hline 845 & 》 & 18 & 》 & 5 & $》$ & - & " & 13. \\
\hline 84 & $\gg$ & 21 & , & 5 & & - & " & 16. \\
\hline 34 & & 19 & $\gg$ & 2 & $\therefore$ & 一 & » & 17. \\
\hline & 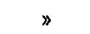 & 13 & » & 3 & » & - & 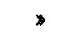 & 0. \\
\hline & » & 24 & 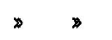 & 8 & $\gg$ & - & 》 & 16. \\
\hline & • & 22 & > & 8 & , & - & $"$ & 14. \\
\hline & " & 15 & 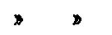 & 5 & 2 & - & & 10. \\
\hline & $\gg$ & 21 & $\gg$ & 14 & " & - & 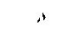 & \\
\hline 35 & $x$ & 19 & , & 4 & * & - & 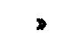 & 15. \\
\hline
\end{tabular}

fødes 185 og dor 60 børn - rest 125 . (32,4\% døde.)

1854 fødes 15 og dor 8 børn - rest 7 .

1855,17 , 6 , 6 , 11.

$1856,22,3$, $\quad 319$.

1857 " 18 " 7 , 711.

$1858 \times 21 \gg, 8,-13$.

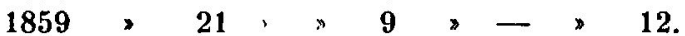

$1860,16 \%, 5,->11$.

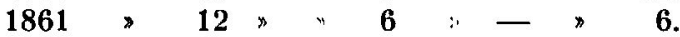

$1862 \times 16 ", 2,-14$.

1863 " $16: 40$ : 016.

fodes 174 og dor 54 born - rest 120 . (31 \% dode.)

Når man som her ligeledes af praktiske grunde inddeler tidsrummet i 10-år, ser man ret, hvor forfærdeligt et omfang børnedødeligheden har haft.

Helt til op mod 1800 tallet har det altså varet regelen, at hvert andet barn skulle dø, inden det var nået til skelsalder. I det 19. århundredes første ti-âr er der en tendens til nedgang, så det kun bliver hvert 3 . eller 4 . barn, som er market til død. I de sidste ti-år op mod vor periodes slutning er der igen tendens til stigning. Hvert 3. barn skal dø. 
Ser man nu tallene nøjere efter, vil man snart kunne udskille de særlig mørke og onde år, hvor dødstallene er meget store. Det ser ligefrem ud til, at der er tale om epidemier.

Dette bekræftes, når vi nu går over til i enkeltheder at undersøge de enkelte års børnedødsfald.

\section{5.}

1. 24. juli dør en pige $6^{1 / 2}$ år gl.

2. 10. september dor en pige 25 uger gl.

3. 19. september dør en dreng 12 dage gl.

4. 28. november dør en dreng 24 timer gl.

5. 1. december dor en pige $1^{1 / 2}$ år gl.

6. 18. december dor en pige $2^{1 / 2}$ år gl.

\section{6.}

7. 6. januar dør en pige $2^{1 / 2}$ år gl.

8. 20. januar dor en pige 2 år gl.

Her er selvfølgelig meget usikkert. Ingen kan vide, om disse børn er døde af samme sygdom. Men når så mange dødsfald følger så nær hinanden i tid, taler sandsynligheden for det.

Den næste epidemi synes tydeligere. Den begynder omkring august 1778 og ser sådan ud:

1778 .

1. 12. august dør en dreng 11 år gl.

2. 21. august dør en pige 1 år gl.

3. 2. september dør en pige 3 måneder gl.

4. 1. november dør en pige 3 måneder gl.

5. 8. november dor en dreng $3^{1 / 2}$ år gl.

6. 27. november dør en pige $3 \stackrel{a}{\mathrm{r}} \mathrm{gl}$.

7. 29. november dør en dreng $2^{1 / 2}$ år gl.

8. 30. november dor en dreng 5 år gl.

9. 10. december dør en pige $3^{1 / 2}$ år gl.

10. 15. december dør en dreng 8 måneder gl.

11. 16. december dør en pige 2 år gl.

12. 21. december dor en pige $2^{1 / 2}$ år gl.

1779.

13. 9. januar dør en pige 2 år gl.

At det her er samme smitte sandsynliggøres ved, at henholdsvis nr. 3 og $6 ; 8$ og 12; 10 og 11 er søskende.

I 1784 kommer en ny epidemi, og ialt 8 børn dør fra april til august. 


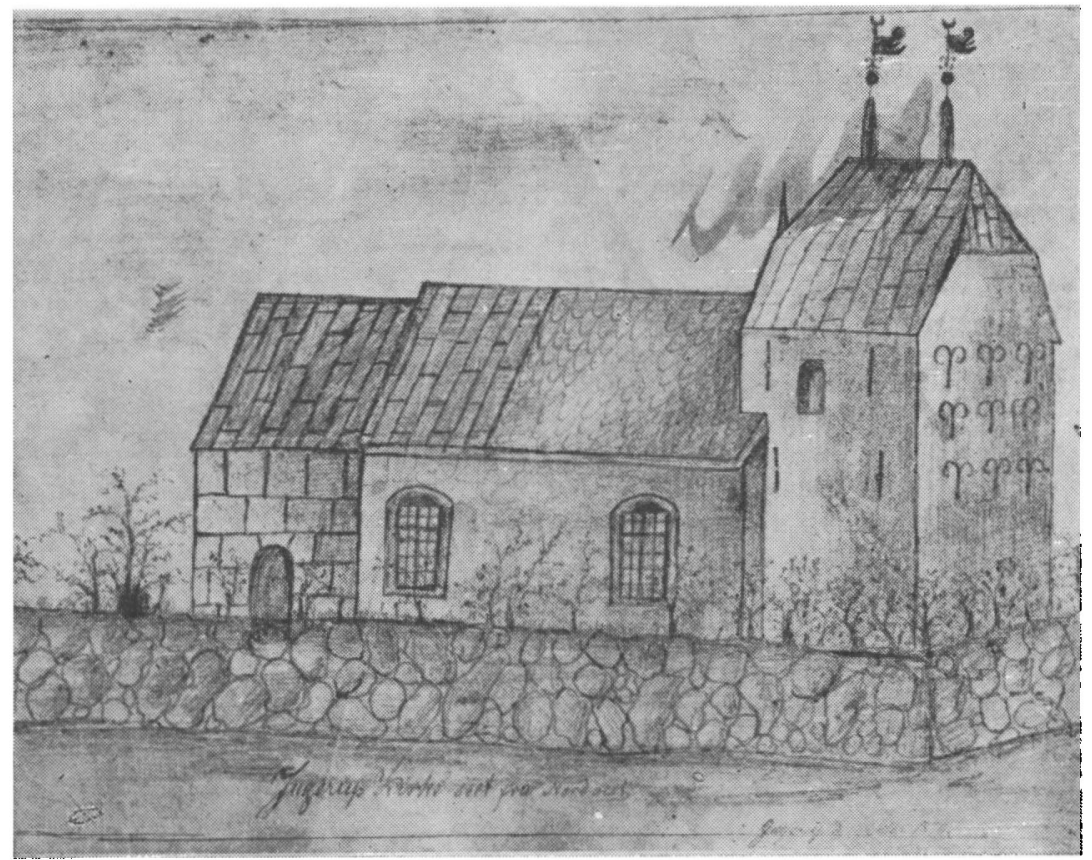

Jegerup kirke 1870, tegnet af J. P. Biel, Jegerup. (Foto: Brdr. Borg).

Men i 1794 bliver det helt galt. Her ser listen således ud:

1794.

3. januar dør en dreng $6^{1 / 2}$ år gl.

7. januar dør en pige 5 måneder gl.

8. januar dør en dreng 1 år gl.

11. januar dør en pige 15 uger gl.

14. januar dor en pige $3^{1 / 2}$ år gl.

15. januar dør en pige $2^{1 / 2}$ år gl.

18. januar dor en pige 2 år gl.

24. januar dor en pige 1 år gl.

25. januar dor en dreng 2 år gl.

27. januar dor en pige $1^{1 / 2}$ år gl.

29. marts dor en pige $3^{1 / 2}$ år gl.

26. april dør en dreng $4^{1 / 2}$ år gl.

23. juli dor en dreng $1 \frac{1 / 2}{2}$ ar gl.

30 . oktober dør en pige $5^{1 / 2}$ år gl.

10. november dør en dreng 6 maneder gl.

13. december dør en dreng 7 måneder gl.

Hvilken børnesygdom, det her har drejet sig om, kan vi jo ingen 
mening have om, men at det har været samme smitte, som har bragt de første 11-12 børn døden, er da mere end sandsynligt.

Næste morke âr tegner sig omkring 1800.

1799.

1. 3. oktober dor en pige 5 dage gl.

2. 28. november dør en dreng 7 år gl.

1800.

3. 13. januar dor en dreng $1^{1 / 2}$ air gl.

4. 18. februar dor en dreng $1 \frac{1}{1} / 2$ år gl.

5. 11. juni dor en dreng 7 år gl.

6. 18. juni dor en dreng 1 år gl.

7. 15. oktober dor en dreng $1 \frac{1 / 2}{2}$ år gl.

8. 14. november dør en dreng 6 ir gl.

9. 14. november dor en dreng 4 år gl.

10. 27. november dør en pige 7 år gl.

11. 7. december dor en pige 1 år gl.

12. 9. december dor en pige $2^{1 / 2} \mathrm{år} \mathrm{gl}$.

13. 14. december dor en pige 1 år gl.

14. 17. december dor en pige $3^{1 / 2}$ år gl.

Her fordeler dødsfaldene sig jo så spredt, at de vel ikke kan skyldes samme sygdom.

Men nu går vi helt frem til 1826, hvor der nævnes ordet "smitte".

1826.

1. 19. december dor en pige $13 \stackrel{\text { å }}{\mathrm{gl}}$.

2. 20. december dor en dreng 9 måneder gl.

1827.

3. 20. januar dor en dreng 4 år gl.

4. 29. januar dor en dreng $15^{1 / 2}$ air gl.

5. 10. februar dor en dreng 8 måneder gl.

6. 14. februar dor en dreng 6 måneder gl.

7. 21. februar dor en pige 4 uger gl.

8. 22. februar dor en dreng 11 ár gl. (dede af en smitte).

9. 2. april dør en pige 5 måneder gl.

10. 10. april dor en pige $2^{1 / 2}$ år gl.

11. 12. april dor en dreng 11 mineder gl.

12. 26. april "dør Peter Jochumsen pă Voiens, ${ }^{3}$ var givt pa Giravenstein, havde ingen born, dode $\mathrm{i}$ koldfeberen ${ }^{4} \mathrm{i}$ en alder af omtrent $30 \mathrm{ar}$.

13. 2. maj dor en dreng 9 míneder gl.

14. 16. maj dor en dreng 2 år gl.

15. 7. juni dor en dreng $1^{1 / 2}$ ăr gl.

16. 17. juli dor en pige $17 \mathrm{ar}$ gl.

17. 20. juli dor en pige $1^{1 / 2}$ år. gl.

18. 25. september dor en dreng 2 måneder gl. 
Var den »smittex, børnene døde af, den »koldfeber«, som gartneren på Vojensgård bukkede under for? Næppe, når det er den sygdom, det drejer sig om.

Det følgende år, som ikke hører til de helt "mørke» år, hvad dødelighed angår, tager vi også med, idet der også her er angivet dødsårsag. (Her tager vi også et par voksendudsfald med, fordi dødsårsagen er meddelt).

1828.

1. 16. februar dør en dreng 6 år gl. (døde af mæslinger).

2. 20. februar dør en dreng 1 år gl. (døde af mæslinger).

(Disse to var brodre).

3. 7. april dør en dreng 9 måneder gl.

4. 7. maj dør en dreng $17^{1 / 2}$ år gl. ("han døde af tæresygec). ${ }^{5}$

5. 26. juni dør en dreng 7 år gl.

6. 30. juni dør en dreng 7 măneder gl.

7. 5. august dor en kone 31 år gl. (shun døde af tresesygex).

8. 11. november dør en pige 7 måneder gl.

9. 30. december dør en mand 49 år gl. ("han dode af en brystsyge «).

Her er altså for forste gang mæslinger nævnt som dødsårsag, men også słresygdommen ", altså tuberkulosen, som nu bliver den frygtede folkesygdom.

Den næste liste, vi vil se på, er den, som begynder i 1833 .

1833.

1. 29. juni dør en dreng 6 år gl.

2. 24. august dør en dreng 3 år gl.

3. 8. september dør en pige $1^{1 / 2}$ år gl. (søster til nr. 2).

4. 18. november dor en dreng 6 måneder gl.

1834.

5. 19. januar dør en dreng 14 dage gl. (broder til $\mathrm{nr} .2 \mathrm{og} \mathrm{3}$ ).

6. 28. januar dør en pige 10 måneder gl.

7. 1. februar dør en pige 7 år gl. (skarlagens-feberen).

8. 11. februar dør en dreng 7 måneder gl.

9. 13. februar dør en dreng $2^{1 / 2}$ år gl. (skarlagens-feberen).

10. 14. februar dor en pige 6 år gl. (skarlagens-feberen). (Søster til nr. 4).

11. 18. februar dør en dreng 3 i̊r gl. (skarlagens-feberen). (Broder til nr. 9).

12. 29. februar dør en dreng $8^{1 / 2}$ år gl. (skarlagens-feberen). (Broder til nr. 10).

13. 2. marts dør en dreng 16 år gl. ("døde af tæresyge๔).

14. 2. marts dør en dreng $1^{1 / 2}$ år gl. 
Her var det altså skarlagensfeberen, som var den onde sot, der ryddede op i hele søskendeflokke.

Det næste år, vi tager med, er 1837. Det er heller ikke af de særlig slemme år, men det viser igen, hvordan enkelte søskendeflokke rammes særlig hårdt.

1837.

1. 26. januar dør en pige 2 år gl. (søster til nr. 5,1834 ).

2. 1. februar dør en pige $1^{1 / 2}$ år gl.

3. 7. februar dør en dreng $3^{1 / 2}$ år gl.

4. 10. februar dør en dreng 2 år gl.

5. 24. marts dør en dreng 1 år gl.

6. 3. april dør en dreng 2 år gl. (broder til nr. 4, 1833).

7. 2. juni dør en dreng 3 måneder gl. (broder til nr. 6, 1837).

Nu går vi helt frem til 1852, som også er præget af et uhyggeligt antal dødsfald blandt børnene.

1852.

1. 22. januar dor en pige 12 uger gl.

2. 25. januar dør en pige $1^{1 / 2}$ är gl.

3. 27. januar dør en dreng 15 år gl.

4. 12. februar dor en dreng 5 år gl.

5. 20. februar dor en dreng 19 uger gl.

6. 6. marts dor en pige 3 år gl.

7. 15. marts dør en dreng $4^{1 / 2}$ år gl.

8. 15. maj dør en dreng 1 år gl.

9. 8. juni dør en dreng $2^{1 / 2}$ år gl.

10. 20. juni dør en dreng 6 måneder gl.

11. 1. juli dør en dreng 8 dage gl.

12. 19. september dør en pige $7^{1 / 2}$ i̊r gl.

13. 19. september dor en dreng 1 år $g l$.

14. 3. december dør en pige 2 måneder gl.

Her må vel også være tale om smitsom sygdom, men der er ingen antydning af, hvilken sygdom det drejer sig om. Heller ikke synes nogle af børnene at være fra samme hjem.

Vi vil nu til slut nævne en hel række fra 1857 til hen imod 1860, hvor dødsårsagen i mange tilfælde er angivet. For 1857 nævnes også nogle voksendødsfald, idet vi her har den eneste antydning af en forgrening af en epidemi, som også kendes andet steds. 1857.

1. 14. marts dør en pige $1^{1 / 2}$ år gl.

2. 26. marts dør en dreng 2 år gl.

3. 1. juni dør en dreng 3 år gl. ("døde af strubehoste «). 
4. 4. juni dør en pige $1^{1 / 2}$ år gl. (>døde af strubehoste ). (Søster til nr. 3, 1857).

5. 19. juli dor en dreng 2 år gl.

6. 13. oktober dør en ung mand 22 år gl. ("døde af blodgang «).

7. 15. oktober dor en mand 52 år gl. (vdøde af blodgang s). (Fader til nr. 6, 1857).

8. 1. november dør en gammel mand 81 år gl. (»døde af blodgang «).

9. 4. november dør en pige 3 år gl. (»døde af strubehoste $\varsigma$ ).

10. 20. november dor en ung mand 32 år gl. (»døde af blodgange).

11. 5. december dør en dreng $1 \frac{1 / 2}{2}$ år gl. (sdøde af mæslinger ).

1858.

12. 14. januar dør en pige 2 år gl.

13. 11. marts dor en dreng 5 måneder gl.

14. 10. juni dor en pige 1 år gl.

15. 11. juli dør en dreng 11 år gl.

16. 25. august dør en pige 9 år gl.

17. 15. december dør en dreng 2 dage gl.

18. 27. december dør en dreng 5 år gl. (odøde af hjernebetændelse $)$ ).

19. 28. december dør en pige 2 år gl. (s skarlagens-feberen «).

1859.

20. 7. januar dor en pige 13 år gl.

21. 16. januar dør en dreng $1^{1 / 2}$ ăr gl. (*skarlagens-feberen *).

22. 12. februar dor en dreng 2 år gl.

23. 23. februar dør en pige 8 måneder gl.

24. 6. marts dor en pige $16^{1 / 2}$ år gl.

25. 6. april dør en dreng 4 år gl.

26. 7. august dør en pige $4^{1 / 2}$ år gl. ( s skarlagens-feberen «).

27. 14. august dør en pige 8 år gl.

28. 17. november dør en dreng 10 uger gl.

Her bliver det jo rigtig tydelig, hvor forsigtig man må være, når man vil angive dødsårsagen. At dødsfaldene falder sammen $i$ tid, behøver ikke at betyde, at det drejer sig om samme sygdom. På den anden side kan samme sygdom holde sig på samme sted $i$ måneder (jvf. nr. 191858 og 26 1859).

Og resultatet af vor undersøgelse bliver da en fornemmelse af, at det ikke blot var de store farsoter, som bremsede udviklingen og lod befolkningstallet stagnere, ${ }^{8}$ men at det frem for noget var de ganske ordinære børnesygdomme, som aldrig slap deres tag. Når de havde raseret blandt sognets børn fra en kant, kunne de få år efter tage turen den anden vej.

Når vi standser undersøgelsen omkring 1863 , er det ikke bare af den grund, at 100 år er et passende rundt tidsafsnit, men mere fordi sognet nu begynder at skifte karakter. 
Med den nye jernbane kommer sognets tyngdepunkt snart til at ligge ved stationen, som bygges på Billunds bymark, men får navnet Vojens station. Og kirkebogens "De Dødes Register" fortæller ikke mere kun om et lille landsogns døde."

Det betyder ikke, at sundhedstilstanden forbedres. 'Tværtimod har man indtryk af, at en sygdom som tuberkulosen nu rigtig får fat. ${ }^{10}$ Men det er en anden historie.

Men tilbage står indtrykket af døden som den sikre gæst $i$ barnekammeret. Kirkebogen melder kun om de tilfælde, hvor denne mørke gast tog sig betalt, og en ny barnegrav kastedes på den gamle kirkegård. Den nævner ikke de tilfæelde, hvor en mors bøn og kamp lykkedes, og barnet kom sig.

Et mørkt kapitel om feberskinnende øjne, som i angst stirrer ud fra mørke alkover - men også et lyst kapitel om heltemodige mødre, som mả kæmpe kampen for deres børns liv, kæmpe til det sidste, ja, længere endnu. Thi var slaget tabt og den lille sjæl givet i Guds hånd, sâ var tiden jo endnu for hånden, da en livets sejr skulle vindes i barselsengen.

Ja, det var dem, som nåede en kvindes mål: at blive mor. Men det nåede jo ikke alle. De mange dødfødte ${ }^{11}$ viser os jo hen til de i sandhed ulykkelige: de, som kæmpede helt forgæves.

Lad os til slut nævne et eksempel.

Den 5. december 1778 er der fest på den kgl. forpagtergård Woyens-Gaard. ${ }^{12}$ Den forrige forpagters eneste søn, Rasmus Rasmussen, bliver copuleret til jomfru Gunder Lena Boessen, datter af arve-pagter til Ahrendorph Mølle, Hans Petersen Boessen.

Et år $\mathrm{i}$ forvejen døde den gamle forpagter 88 år gl. efterladende sig foruden sønnen, som havde samme navn som faderen, syv døtre. Det er altså en livskraftig familie, hvor man må vente et myldrende barnekammer.

Men 5. maj 1780 bliver det til en dødfødt pige. Året efter den 29. marts fødes der vel en søn, som skyndsomst ved dåben nævnes med faderens og bedstefaderens navn Rasmus Rasmussen - og så dør den lille 1 dag og 7 timer gl.

27. december 1782 kommer så en dødfødt søn, og 23. september 1783 dør Madame Gunder Lena Rasmussen 31 år gl. »uden Liivsarvinge $\times$. 
Næste år den 22. maj fører enkemanden Gunder Lenas søster til brudeskamlen. Også denne gang er efter rang og stand 'med Kgl. Consession til Huus-Copulation «. Der går et par år, så føder Madame Catharina Elisabeth Rasmussen en lille pige, som hastigt døbes med navnet Lena Maria - men kun 1 time efter dør. Og heller ikke siden lykkedes det.

»Ei døden agter alder stort — men heller ikke rigdom, rang eller stand kan garantere mod den største ulykke af alle: den, aldrig at have levet!

\section{NOTER}

1. Fra $\gg$ Den Pontoppidanske Psalme-Bog $₫$. Her udg. 1883. Salmen findes også i Den Sønderjydske Salmebog nr. 553, her opgives den skrevet 1665 af Gottfr. W. Sacer og oversat til dansk 1740. Se iovrigt A. Malling: Dansk Salme Historie III 156-160.

2. Jegerup sogn bestâr $i$ hele dette tidsrum af hele det område, som omfattes af Jegerup og Vojens kommuner indtil 1. april 1961. Iflg. Trap havde dette område i 1860 en befolkning på henhv. 375 og 265 indb.

3. "på Voiens * betyder som regel på Vojensgård. Vojens var vel oprindelig en landsby, som i 1475 synes at have haft mindst 10 gåde. I îret 1659 skal ialt 11 gårde være brændt og øde (f. eks. Johs. v. Schröder: Topographien des Herz. Schleswig p 447). Men allerede 1580 synes Vojensgård at have været $\mathrm{kgl}$. forpagtergård.

4. Malaria. På grund af denne sygdoms særlige smitteform, fra menneske til myg og fra myg til menneske kan der jo næppe være tale om direkte smitte.

5. 'Tußerkulose.

6. Der kan her være tale om den såkaldte "falske strubehoste laryngitis, men muligt er det en betegnelse for difteri (Angina diphtheritica).

7. Dysenteri. Der har været en farlig epidemi her på egnen. I året 1857 dode f. eks. i Hoptrup sogn ikke færre end 85 mennesker, mens det normale var ca. 30. Årsagen var blodgang. (Her iflg. Sædekornet $1912 \mathrm{nr}$. 48).

8. Her må i almindelighed henvises til Aksel Lassen: Skæbneåret 1659. Ovenstiende undersøgelse står i gæld til dette dygtige arbejde, og er egentlig blot et forsøg på - indenfor et så lille område som et enkelt sogn - at fortsætte dets linie.

9. 1860 havde den sydlige del af sognet, som nu kaldes Voiens, alene ca. 265 indbyggere.

10. Af de 136 dodsfald i årene 1964-73 skyldes 19 el. ca. $14 \%$ tuberkulosen - idet der her kun nævnes de sikre angivelser af dødsårsag.

11. Jvf. side $200 \mathrm{f}$.

12. Jvf. note 3 . 